Towarzystwo Biblijne w Polsce

\title{
Słowo na Ekumeniczne Dni Biblijne $2007^{1}$
}

Hasłem tegorocznego ekumenicznego święta Biblii są następujące słowa wypowiedziane przez Boga, a zawarte w Księdze Izajasza: „Oto ja czynię rzecz nową: już się rozwija, czy tego nie spostrzegacie?” (Iz 43, 19).

Słowa te są jednym z piękniejszych i bardziej wyrazistych fragmentów szerszego tekstu proroczego powstałego po upadku Północnego Państwa Izraelskiego w roku 722 przed Chr. Tekst ten opisuje m.in. inwazję króla asyryjskiego Sancheryba na Jerozolimę cudownie ocaloną przez Boga. Mówi o chorobie i wyzdrowieniu ówczesnego króla judzkiego Hiskiasza. Relacjonuje wizytę złożoną mu przez poselstwo babilońskiego władcy Merodacha-Baladana. Niestety nie została ona w pełni wykorzystana przez króla dla chwały Bożej, co spowodowało późniejszy dramat niewoli babilońskiej (w roku 586 przed Chr.).

Były to czasy bardzo trudne, nacechowane upadkiem religijnym i narodowym. Ale właśnie wówczas między tragedią Samarii i Jerozolimy zabrzmiało wspaniałe przesłanie Boże skierowane do wierzących tamtych czasów. Odbija się ono kilkakrotnym, coraz bardziej spotęgowanym echem wezwań Bożych występujących w późniejszych pokoleniach: „Oto ja czynię rzecz nową: już się rozwija, czy tego nie spostrzegacie?”. W przesłaniu tym zawarte zostało słowo pocieszenia i nadzieja obecności Boga wśród Jego ludu oraz działań Bożych mających na celu zbawienie wierzących i odnowę wszystkiego. Przede wszystkim przesłanie Boże z czasów Izajasza zawierało zapowiedź odnowy królestwa Judy po powrocie z niewoli babilońskiej. Następnie roztaczało wizję odkupieńczej misji Chrystusa i powołania nowego Izraela, to jest Kościoła, z jego uniwersalnym poselstwem Ewangelii. Ukazywało wreszcie zbawcze dzieło Boże, którego kulminacja nastąpi w wielkim dniu powtórnego przyjścia Pana, oraz ostateczne urzeczywistnienie Królestwa Bożego, królestwa chwały i pokoju, w którym wola Boża

${ }^{1}$ Tegoroczne słowo przygotował Kościół Adwentystów Dnia Siódmego w Rzeczypospolitej Polskiej. 
realizowana będzie na ziemi tak jak w niebiosach. O to właśnie modlimy się codziennie w modlitwie Pańskiej Ojcze nasz.

Przesłanie Izajaszowe „Oto ja czynię rzecz nową” szczególnie uroczyście rozbrzmiewa w naszych czasach. Czyż nie jest „rzeczą nową” fakt wspólnego i zgodnego gromadzenia się wokół Biblii przedstawicieli różnych wyznań, a także wspólna ekumeniczna modlitwa i współdziałanie chrześcijańskich Kościołów dla dobra człowieka i chwały Boga? Przecież do niedawna w naszym kraju nie do pomyślenia była np. współpraca nad ekumenicznym przekładem Biblii? A co sądzić o współczesnych wydarzeniach i wielkich znakach czasu wskazujących na powagę dni, w których żyjemy? Czyż nie są one wezwaniem do odnowy naszego ducha i życia chrześcijańskiego? Pan czyni „nowe rzeczy”. Dostrzegamy to? Przecież wszystko ,już się rozwija”.

Ekumeniczne święto Biblii skupia nas wokół słowa Bożego, zachęca do studiowania Pisma Świętego oraz życia zgodnego z jego nauką. Znana adwentystyczna pisarka Ellen G. White często przypominała: „Polecam ci, drogi czytelniku, Słowo Boże jako zasadę swej wiary i życia. Przez to Słowo będziemy sądzeni”. Drugi List do Tymoteusza mówi natomiast: „Całe Pismo Święte przez Boga jest natchnione i pożyteczne do nauczania, przekonywania, upominania, do wychowywania w sprawiedliwości, aby człowiek Boży był doskonały, przygotowany do wszelkiego dobra”.

Niech Bóg będzie uwielbiony. Alleluja!

TOWARZYSTWO BIBLIJNE W POLSCE 